\title{
Monitoring of the Visitors Impact at "Ponta da Ferraria e Pico das Camarinhas" Geosite (São Miguel Island, Azores UNESCO Global Geopark, Portugal)
}

\author{
Ana Lima ${ }^{1}$ • João Carlos Nunes ${ }^{2}$. José Brilha ${ }^{3}$ \\ Received: 19 April 2016/Accepted: 17 October 2016 \\ (C) The European Association for Conservation of the Geological Heritage 2016
}

\begin{abstract}
Ponta da Ferraria e Pico das Camarinhas" is a protected geosite in São Miguel Island in the Azores archipelago, Portugal. Due to its importance for the geoconservation strategy of the Azores UNESCO Global Geopark, monitoring actions of visitor impact were implemented in order to assure that the main geological features of this geosite continue to be in a favourable status of conservation, taking into account present public use. Different types of data were collected over a one-year period aiming at the identification of factors that may affect the geosite and also the assessment of the eventual decrease of relevance that this geosite has experienced throughout that period. Among the many geological features that occur in the geosite, the littoral cone (or pseudocrater) was considered the most threatened due to its uniqueness and high vulnerability. The number of visitors was also analysed with respect to the geosite's carrying capacity. The monitoring of this geosite allowed the definition of practical actions, in particular to be addressed to the governmental agency who is responsible for the management of this geosite.
\end{abstract}

\section{Ana Lima \\ annafilima@gmail.com \\ João Carlos Nunes \\ jcnunes@uac.pt \\ José Brilha \\ jbrilha@dct.uminho.pt}

1 Earth Sciences Centre, University of Minho, Campus de Gualtar, 4710-057 Braga, Portugal

2 University of Azores \& Azores UNESCO Global Geopark, Rua Mãe de Deus, 9501-801 Ponta Delgada, Açores, Portugal

3 Institute of Earth Sciences, Pole of the University of Minho, Campus de Gualtar, 4710-057 Braga, Portugal
Keywords Azores UNESCO Global Geopark · Monitoring · Geoconservation $\cdot$ Carrying capacity $\cdot$ Geosite

\section{Introduction}

In everyday language, monitoring can be interpreted as the act of measuring a certain topic. This activity can be based on systematic observations of certain aspects related to a specific problem in order to gather information on the characteristics of this problem and its evolution over time (Spellerberg 1991). The repetition of measurements or observations over time for the purpose of detecting changes distinguishes monitoring from inventory and assessment. An inventory or assessment is usually the first step for the establishment of a monitoring project, since the knowledge of the spatial and temporal characteristics of the study area is essential to develop an efficient monitoring strategy (MacDonald et al. 1991). A vast range of features can be monitored in natural sciences, including vegetation growth, animals' behaviour, climate variations, earthquakes or volcanic events. Also, geoconservation strategies (Henriques et al. 2011) use monitoring to understand the evolution of a geosite's relevance over time (Wimbledon et al. 2004, García-Cortés et al. 2012, Brilha 2016, Díez-Herrero et al. 2015, Vegas et al. 2015).

Monitoring is an important tool in environmental planning and management because it provides the necessary information to determine if a resource or a process continues to be affected by a certain threat, or otherwise, is recovering due to the implementation of appropriate management practises (Marion and Leung 2011; García-Cortés et al. 2012; Vegas et al. 2015).

The monitoring of management plans aims to check if their objectives are being met, if the selected strategies are the most adequate to meet the objectives and if the proposed actions were effectively implemented (Portugal 2002). 
This paper presents and discusses an assessment of visitor impact between October 2011 and October 2012 at the "Ponta da Ferraria e Pico das Camarinhas" Natural Monument, one of the geosites in the Azores UNESCO Global Geopark (Lima 2012).

\section{Azores UNESCO Global Geopark}

The Azores archipelago is a Portuguese Autonomous Region located in the North Atlantic, on the triple junction between the North American, Eurasian and African (or Nubian) plates. It is composed of nine islands, some islets and the surrounding seafloor. The islands can be divided into three groups: the Western Group with the Corvo and Flores islands, the Central Group with Faial, Pico, São Jorge, Graciosa and Terceira islands and the Eastern Group with São Miguel and Santa Maria islands (Fig. 1).

The volcanic islands of the Azores present a wide range of landforms, reliefs and structures due to the type of eruptions and rocks produced and subsequent weathering and erosion (Lima 2009). They are characterized by 16 major polygenetic volcanoes and 11 fissural basaltic systems, nine of them being active and located in the islands of São Miguel, Terceira, Graciosa,
São Jorge, Pico, Faial and D. João de Castro Bank (a submarine volcano between Terceira and São Miguel islands). On these 27 volcanic systems, there are about 1750 monogenetic volcanoes, either dispersed along the flanks and inside the depressions in the summit of the polygenetic volcanoes or on the fissural basaltic systems. These monogenetic volcanoes include domes and coulées, tuff rings and tuff cones, maars, scoria and spatter cones and eruptive fissures (Lima et al. 2010).

The international relevance of the Azorean geodiversity, the high number and scientific importance of the geological heritage, together with the rich biological and cultural heritage constituted the background for the Azores government decision to implement a geoconservation strategy through the creation of the Azores Geopark (Lima 2009), which was integrated in the European and Global Geoparks Networks (EGN/ GGN) in March 2013. Lima et al. (2010) have identified 121 geosites in the nine islands and the surrounding sea floor, with international, national and regional relevance. Based on this inventory, 57 main geosites were selected to be included in the management strategies of the Azores UNESCO Global Geopark. "Ponta da Ferraria e Pico das Camarinhas" geosite is one of these geosites.

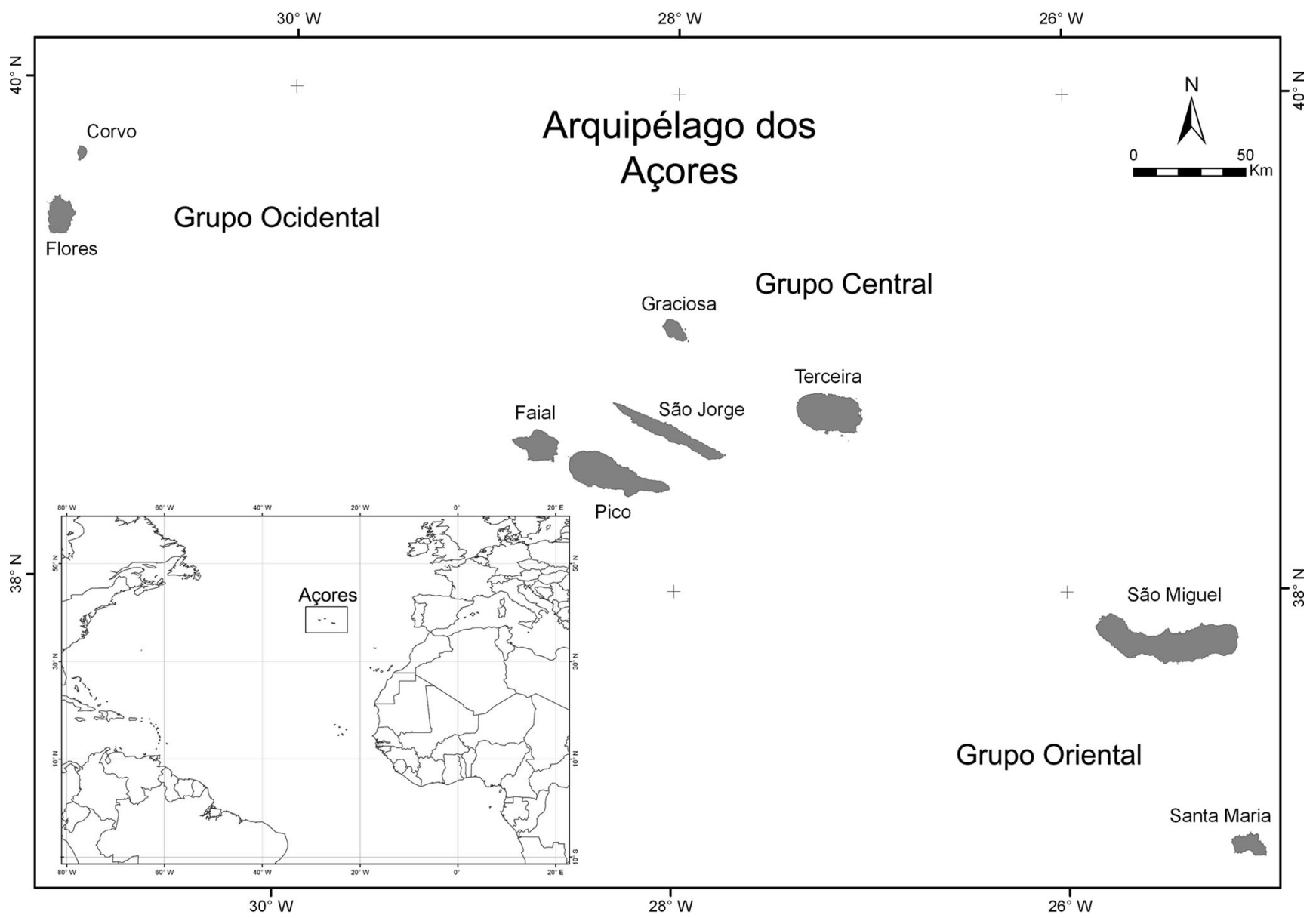

Fig. 1 Location of the Azores archipelago, Portugal 


\section{"Ponta da Ferraria e Pico das Camarinhas" Geosite}

"Ponta da Ferraria e Pico das Camarinhas" geosite is located in the westernmost sector of São Miguel Island (Fig. 1 and Fig. 2). Pico das Camarinhas (Fig. 3) is a basaltic scoria cone with three craters on the summit, elongated along a general WE trend, which defines a radial tectonic alignment of the Sete Cidades central volcano. Ponta da Ferraria (Fig. 2 and Fig. 3) is a lava delta formed by basaltic lava flows, which erupted from Pico das Camarinhas monogenetic volcano $840 \pm 60$ years ago, during one of the 46 flank eruptions of Sete Cidades volcano (Moore 1991; Nunes and Lima 2009). This lava delta, also named as "fajã" in the Azores, has a typical triangular shape, a finger-like shoreline contour, and is characterized by vertical plunging sea cliffs in most of its contour. It has an area of $129,431 \mathrm{~m}^{2}$ and an altitude of about $15 \mathrm{~m}$ in the central part (Nunes and Lima 2009). According to Carvalho et al. (2009), the Ponta da Ferraria lava flow has a thickness of about $20 \mathrm{~m}$, with top and bottom clinkery layers.

There is a fossil sea cliff (Fig. 3) where geological formations of Sete Cidades volcano can be observed, namely, basaltic and trachytic s.l. lava flows, lapilli and pumice deposits, ignimbrites and sub-vertical dykes (Nunes and Lima 2009). Near the natural thermal pool at the southernmost part of the lava delta, Moore (1991) describes a tristanite lava flow in the fossil sea cliff with 74,000 \pm 6000 years B.P. (Fig. 2).

During the movement of the lava flow into the sea, water steam accumulated underneath the lava flow. This steam produced small explosions on the top of the lava delta forming a structure with conical shape, but without a feeding conduit. This structure known as littoral cone or pseudocrater (Fig. 3) is extremely fragile and very rare in the Azores archipelago (Nunes and Lima 2009).

Rocks of Ponta da Ferraria lava flow have a very high concentration of xenoliths/cumulate with a relatively homogeneous mineralogical composition (plagioclase and amphiboles) but with diversified textures. Also, at the northern part of the fossil sea cliff and dispersed in the ankaramitic lava flow and scoria deposit of Várzea Cone (5000 and 15,000 years), there are ultramafic xenoliths of granular rocks rich in olivine and pyroxene, which were initially formed deep in the mantle (Nunes and Lima 2009).

East of Pico das Camarinhas scoria cone, there is an older volcano, a trachytic dome (Fig. 3) associated with the same radial fracture of Sete Cidades volcano. Both volcanoes were fed through the same magmatic chamber, but they represent two different lithological compositions, trachyte and basalt (Nunes and Lima 2009).

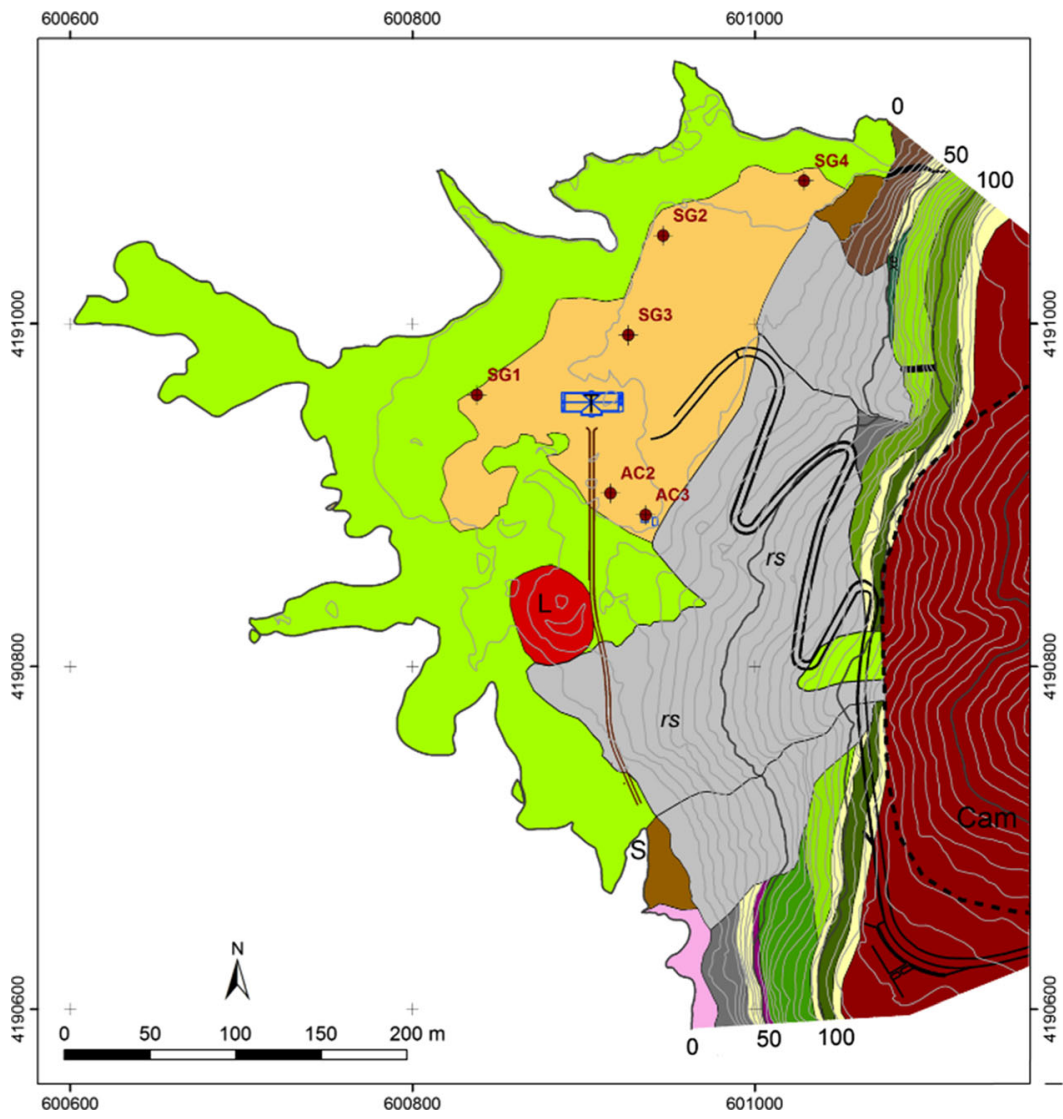

Fig. 2 Geological map of the Ponta da Ferraria area (Nunes and Lima 2009)

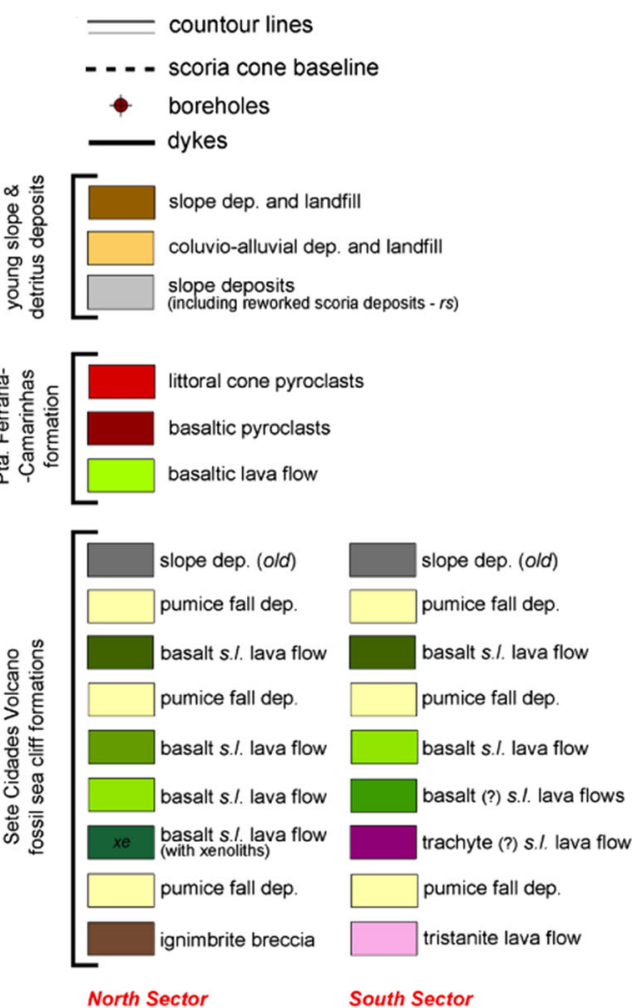

North Sector 
Fig. 3 Main geological features at "Ponta da Ferraria e Pico das Camarinhas" geosite. a Fossil sea cliff. b Pico das Camarinhas scoria cone. c Littoral cone (or pseudocrater). d Trachyte lava dome. e Ponta da Ferraria lava delta. f Natural thermal pool
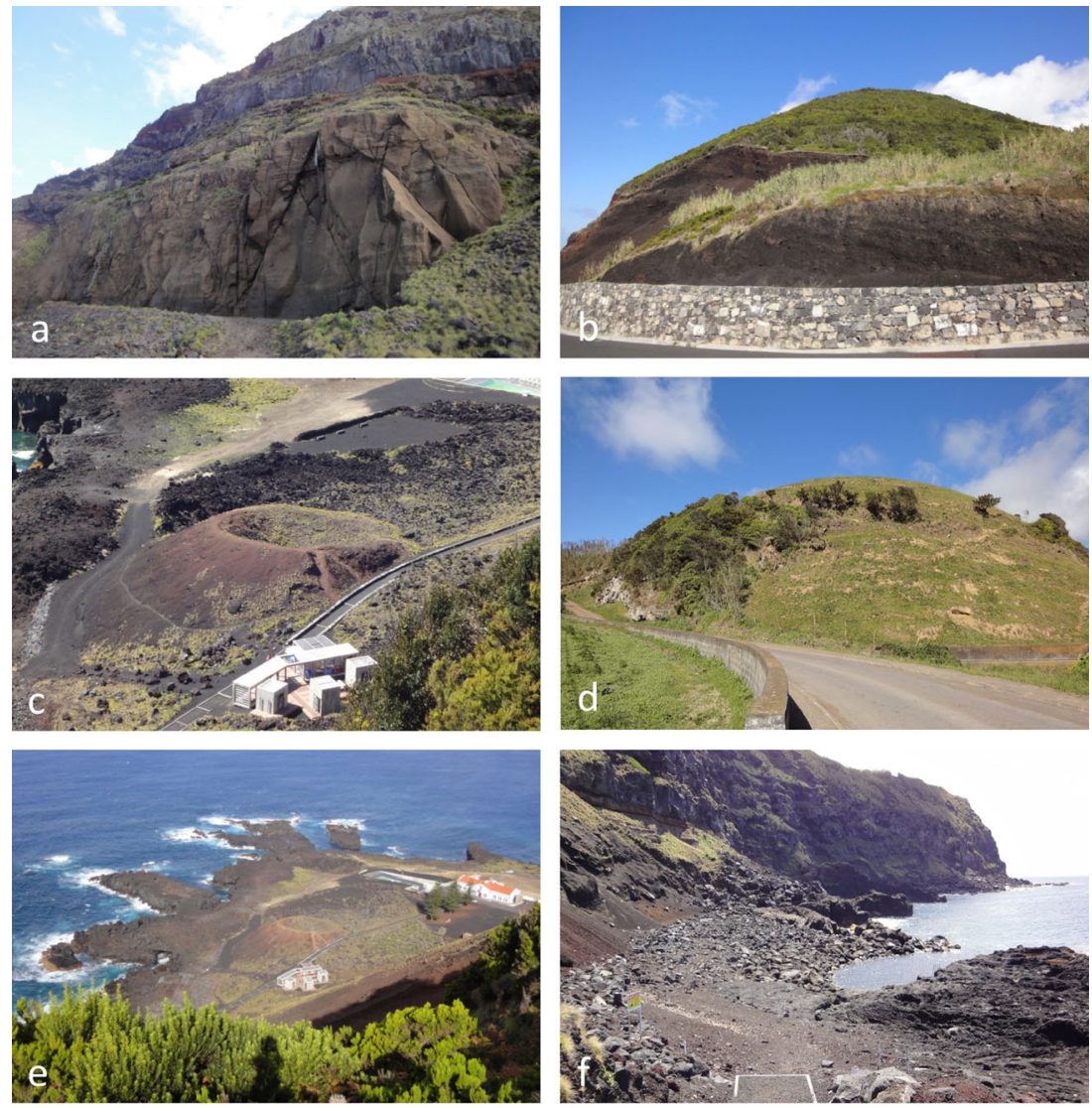

In addition to these geological features, at the southernmost part of Ferraria lava delta, water emerges at the sea level with a temperature of $62.5{ }^{\circ} \mathrm{C}$ (Carvalho et al. 2009); (Fig. 3). Despite the inexistence of subaerial gas emissions in Sete Cidades volcano, submarine fumaroles are known near the Ferraria and Mosteiros coastal areas (Carvalho et al. 2009). The Ferraria thermal water has physicochemical characteristics compatible with an origin resulting from a mixture of seawater and a deep primary fluid that was characterized by Acciaiuoli (1953) as sodium chloride with high mineralization $(20 \mathrm{~g} / 1)$. This thermal water is used in a local spa for health and well-being purposes.

Besides geological and hydrogeological features, this geosite has also cultural relevance. In June 1811, a new volcanic island was formed offshore through a submarine eruption, about 1 mile away from Ponta da Ferraria. This island was completely eroded by the middle of October of the same year, but it was previously named "Sabrina Island" by Captain Tillard. This official of the British navy who was by chance on the area raised the British flag on it, while the island was emerged (Nunes and Lima 2009). Today, the local viewpoint is still known as "Sabrina Island viewpoint", even if this island does no longer exist.

The regional government of Azores has designated "Ponta da Ferraria e Pico das Camarinhas" as a Natural Monument in 2005, due to its unique geological heritage and its historical, geographical, biological, scenic and socioeconomic importance. Concerning the scientific value, this geosite occupies the 14th position among all the 121 geosites of the Azores Geopark and the third position among the 27 geosites of São Miguel island (Lima 2007; Nunes et al. 2011). Presently, it is used for educational, cultural, tourism and science activities; its economic importance is related with the existence of a local spa as a private business (Lima et al. 2010).

Table 1 summarizes the features, sub-features, values and threats of "Ponta da Ferraria e Pico das Camarinhas" geosite (Lima 2012), following the method proposed by Wimbledon (2004). Features are the main geological elements of the geosite, and sub-features correspond to specific geological aspects that characterize each feature. Threats affect the relevance of the geosite such as coastal and slope erosion (natural threats) trampling in the littoral cone, vandalism and littering in the viewpoint, urban pressure on the lava delta and informal quarrying in Pico das Camarinhas scoria cone (anthropic threats).

\section{The Monitoring Strategy}

The monitoring strategy presented in this work aims to evaluate the eventual impact of visitors on "Ponta da Ferraria e Pico das Camarinhas" geosite. It also tries to assess how visitors use the interpretative panel available at the geosite. In 
Table 1 Sub-features, values and threats for each identified feature in the geosite "Ponta da Ferraria e Pico das Camarinhas"

(Lima 2012)

\begin{tabular}{|c|c|c|c|}
\hline Features & Sub-features & Values & Threats \\
\hline \multirow[t]{2}{*}{ Pico das Camarinhas scoria cone } & Multiple craters & Aesthetic & Quarry activities \\
\hline & $\begin{array}{l}\text { Volcanic bombs } \\
\text { Xenoliths/cumulates }\end{array}$ & $\begin{array}{l}\text { Educational } \\
\text { Aesthetic }\end{array}$ & Urban pressure \\
\hline \multirow{3}{*}{ Ponta da Ferraria lava delta } & Costal caves and bays & Educational & Coastal erosion \\
\hline & Columnar jointing & Scientific & Vandalism and littering \\
\hline & Lava flow aa/pahoehoe & & \\
\hline \multirow[t]{2}{*}{ Littoral cone } & Lapilli deposits & Educational & Trampling \\
\hline & Basaltic lava flows & $\begin{array}{l}\text { Scientific } \\
\text { Aesthetic }\end{array}$ & Slope erosion \\
\hline \multirow{8}{*}{ Fossil sea cliff } & Trachytic lava flows & Educational & \\
\hline & Ankaramitic lava flows & Scientific & \\
\hline & Tristanite lava flow & & \\
\hline & Lapilli deposits & & \\
\hline & Pumice deposits & & \\
\hline & Ignimbrites deposits & & \\
\hline & Sub-vertical dykes & & \\
\hline & Ultramafic xenoliths & & \\
\hline \multirow[t]{2}{*}{ Trachyte lava dome } & Siliceous volcanic rock & Educational & - \\
\hline & Alteration processes & Scientific & \\
\hline \multirow[t]{4}{*}{ Natural thermal pool } & Thermal waters & Educational & - \\
\hline & & Scientific & \\
\hline & & Cultural & \\
\hline & & Economic & \\
\hline
\end{tabular}

order to achieve these objectives, (1) the effect of trampling on the littoral cone, (2) the visitors' behaviour regarding the interpretative panel and (3) the number of persons who visit the geosite were observed, measured and registered. For each objective, the method applied and the obtained results will be presented.

\section{Littoral Cone}

The trampling of the littoral cone/pseudocrater of Ponta da Ferraria by visitors has been taking place since at least 1997. However, due to the construction of some barriers in recent years such as ropes and a small wall, the number of people climbing the cone decreased. As previously mentioned, this cone is one of the few and the best preserved examples of this type of volcanic feature occurring in the Azores archipelago. Thus, considering its uniqueness and risk of degradation, the access to the littoral cone was prohibited in 2006, following the designation of "Ponta da Ferraria e Pico das Camarinhas" area as Natural Monument. In order to alert visitors about this restriction, the Azores regional government has installed a ropy-type fence (Fig. 4) and placed a sign alerting visitors not to transpose the fence. The fence was later removed due to vandalism but in July 2012, a new fence was rebuilt. The results obtained allowed us to have a clear picture of the threat and to propose the most appropriate management actions to ensure the conservation of the littoral cone.

\section{Method}

The monitoring actions included the surveillance and registration of the number of people who walked on the cone and the periodic control of the path changes.

The periodic control of changes in two main paths was done using photographic records (Fig. 5 and Fig. 6). These were made in two different scales: with wide photos of the paths and with detailed photos of specific parts of these paths where marks were placed in specific spots to register eventual changes over time. The register of the paths took place between December 2011 and September 2012, and the record of mark changes was done between May 2012 and September 2012.

\section{Results}

Between October 2011 and September 2012, a total of 726 persons were registered. The sample has a confidence level of 95\% and a confidence interval of 5.14. During the monitoring process, some changes occurred, namely, the installation of 
Fig. 4 Main paths at the littoral cone. The paths in dotted lines were monitored with photographical records and through marks (small nails) installed in the edges of the paths. People in red circles for scale purposes

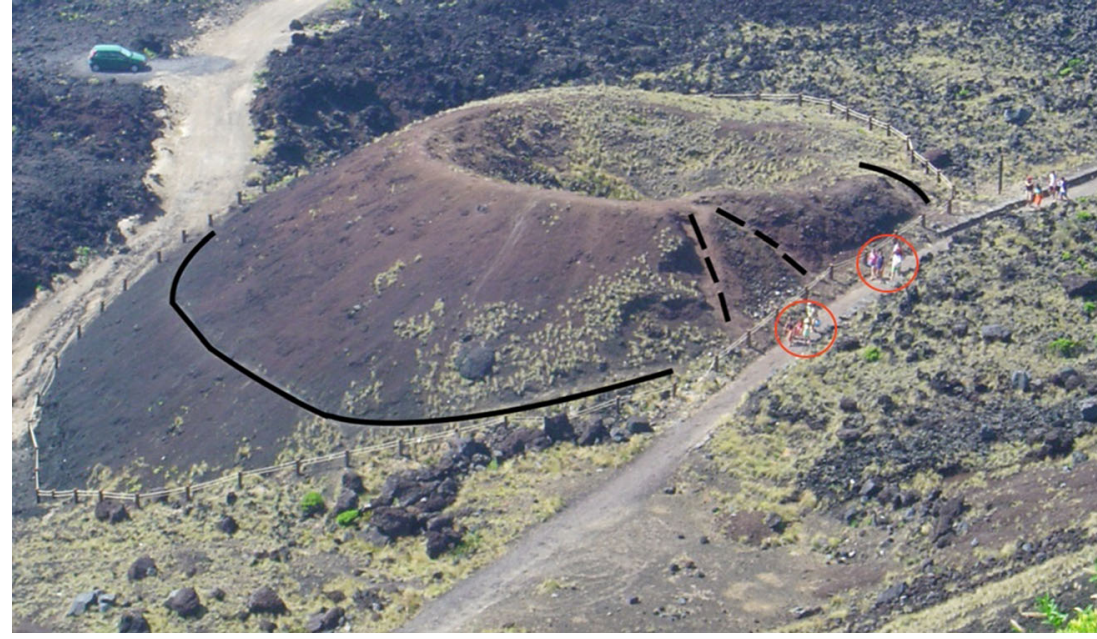

the new fence on the littoral cone. The results of the monitoring of this geosite's features are presented in Table 2. There is a clear dominance of visitors who do not walk on the littoral cone (about 95\%). Evidence shows that the presence of the ropy-type fence does not significantly influence the number of people who trample on the cone $(4.4 \%$ before construction of fence, $3.9 \%$ afterwards).

The photographical records show minor changes in one of the paths. The photo comparison (Fig. 5) between December 2011 and September 2012 show a slight decrease of the grain size of the volcanic material and a smoother surface of the cone. This difference can be explained by trampling or, more likely, by natural erosion (e.g. grain flow slope movements), as only about $4 \%$ of visitors walked on the cone. Regarding the photographic records of marks in specific sections of the paths (Fig. 6), the main differences are related to the change in the grain size of scoria fragments.

\section{Interpretative Panel}

The geosite includes the popular Sabrina Island viewpoint, which offers the possibility to observe most of the geosite's features at the landscape level. The viewpoint includes an interpretative panel with general information about the site. Interpretative panels, in general, help to inform and to explain certain facts of the area, to stimulate the visitor's interest and also to raise awareness for a correct behaviour of visitors.

\section{Method}

Regarding the interpretative panel, the monitoring carried out aimed at counting the time each visitor spent looking at the panel and also registering their behaviour while in front of the panel.
Fig. 5 Photographical record in one of the paths showing differences between December 2011 and September 2012 regarding the grain size of the lapilli and the cone's surface
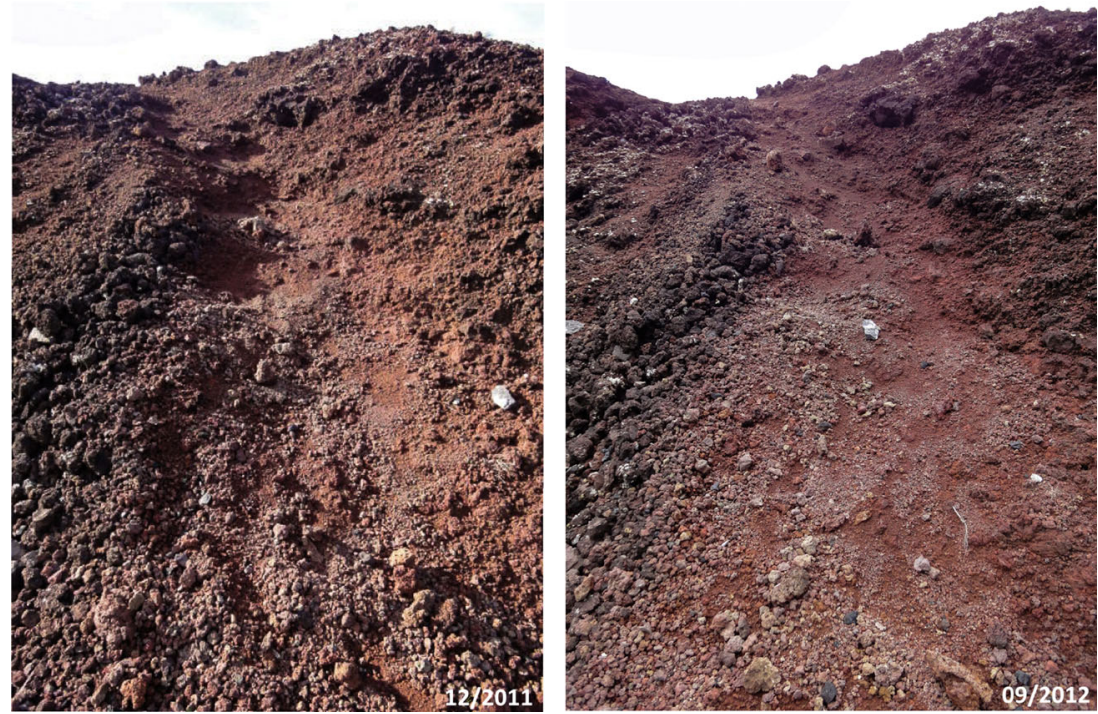
Fig. 6 Photographical record in one of the mark's (circles) showing the difference of the mark's burial level between May 2012 and September 2012
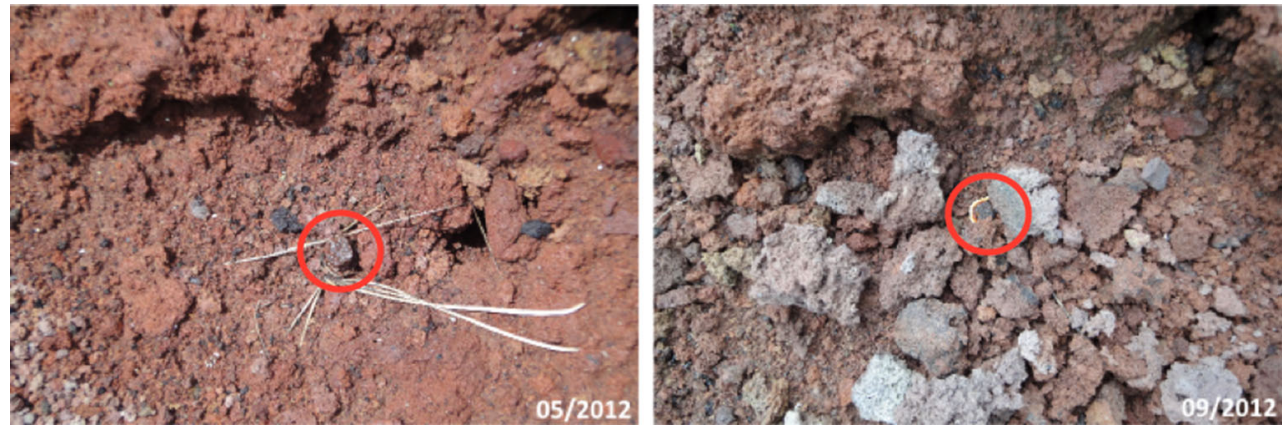

\section{Results}

In order to read the whole interpretative panel, about $4 \mathrm{~min}$ is needed. The results indicate clearly that people do not spend so much time in front of the panel. Most visitors (52.4\%) spent less than $1 \mathrm{~min}, 44.2 \%$ stay between one and $4 \mathrm{~min}$ and only $3.4 \%$ keep reading the panel for more than $4 \mathrm{~min}$. It was also observed that a significant number of persons took a photo of the panel, without even reading it. Some people recognize the image of Pico das Camarinhas volcano when they take a quick look at it. It was also verified that some visitors try to interpret the scheme that is displayed in the panel, which has highlighted some of the geosites's features. In total, 206 persons were registered between October 2011 and June 2012, leading to a sample with a confidence level of $95 \%$ and a confidence interval of 6.83 .

\section{Number of Visitors and Carrying Capacity}

The information about the number of persons who visit a geosite is an important data for the implementation of a correct management. The number of visitors must be adapted to specific characteristics of each geosite, particularly taking into account the fragility and vulnerability of the geological elements that are relevant in the geosite and also the safety conditions for visitors. The monitoring done at "Ponta da Ferraria e Pico das Camarinhas" geosite allowed the evaluation of the number of visitors (tourists and locals) during 1 year (between October 2011 and October 2012). This number was compared

Table 2 Number of people who walk on the littoral cone, without fence and with fence

\begin{tabular}{llllll}
\hline & \multicolumn{2}{l}{ Trampling in the littoral cone } \\
\cline { 5 - 6 } & \multicolumn{2}{l}{ Without fence } & & \multicolumn{2}{l}{ With fence } \\
\cline { 5 - 6 } \cline { 5 - 6 } & AF & RF (\%) & AF & RF (\%) \\
\hline Yes & 16 & 4.41 & & 14 & 3.86 \\
No & 347 & 95.59 & & 349 & 96.14 \\
Total & 363 & 100 & & 363 & 100 \\
\hline
\end{tabular}

$A F$ absolute frequency, $R F$ relative frequency with the potential number of visitors calculated taking into account the carrying capacity of the geosite.

\section{Method}

The monitoring procedure took into consideration the following assumptions:

- The observation spot was the Sabrina Island viewpoint; this is the only possible entrance to the geosite.

- Counting of visitors by direct observation was carried out during the observation period, including tourists and locals.

- A separate note was registered whenever one person visited the geosite more than one time during a day.

- Visitors were counted each day during a six-hour period (10.00-13.00 h, 13.30-16.30 h). An extra counting was done during $3 \mathrm{~h}(17.00-20.00 \mathrm{~h})$ on 3 days during the summer season in order to be able to estimate the maximum number of visitors on a full day.

- The monitoring covered 77 days equally distributed over the whole year to guarantee the representativeness of the observations.

The obtained data were divided into four different periods: a first period with a constant low number of visitors, a second period with many visitors on Sundays, a third period with a progressively increasing number of visitors and a fourth period with a progressively decreasing number of visitors (Fig. 7). For each period, the average number of visitors per day of the week was calculated by extrapolating the data; thus, filling the gaps where no counting was done.

\section{Results}

Along 1 year, 15,903 visitors were recorded during the 77 days of monitoring: 7260 visitors during the morning period and 8643 in the afternoon. Based on the extrapolation of these numbers as described above, an estimated number of 72,789 persons visited the geosite "Ponta da Ferraria e Pico das Camarinhas" 


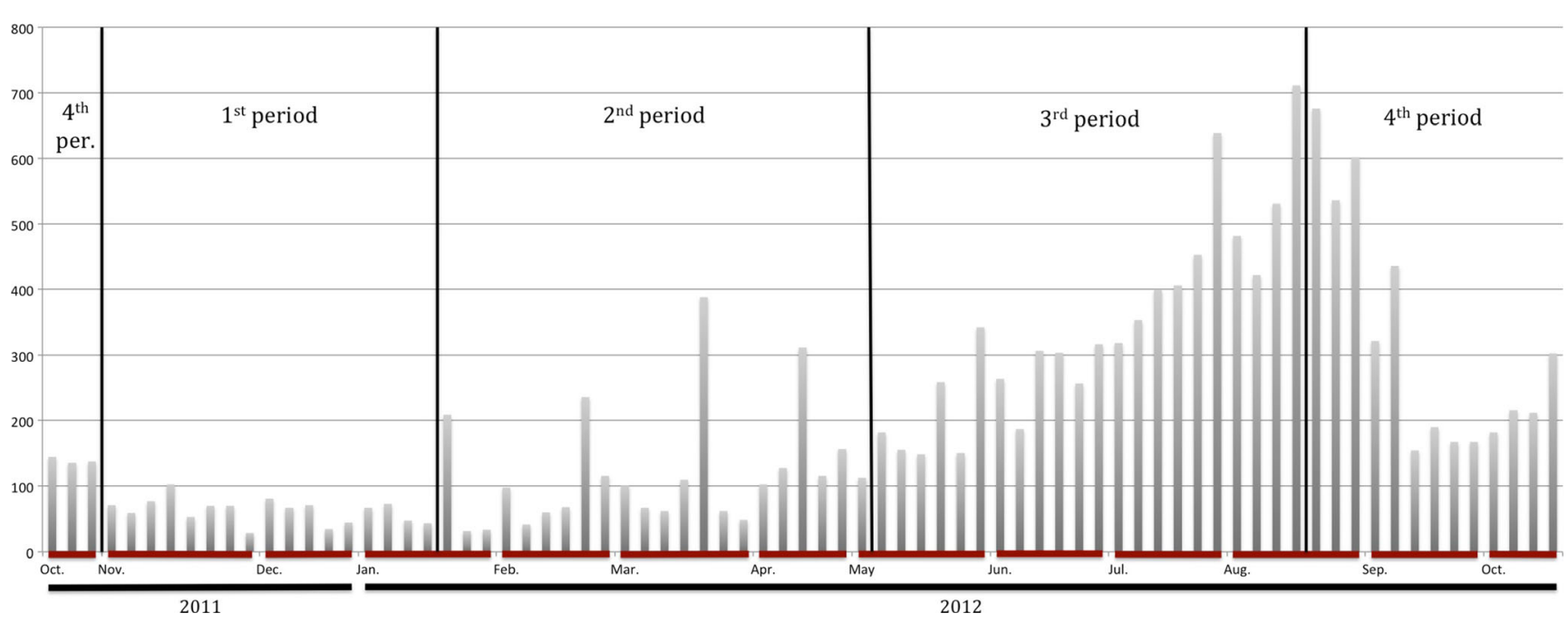

Fig. 7 Number of visitors per day along 1 year (absolute frequency) divided into four periods

between October 20, 2011 and October 21, 2012 (Lima 2012). The highest number of visitors registered during 1 day was 850 (between 10.00 and $20.00 \mathrm{~h}$ on August 27, 2012).

The carrying capacity of this geosite was calculated using an adaptation of the method presented by Cifuentes (1992). This method takes into account several parameters, such as the area available per visitor, the weather conditions, the erosion rate of geological materials, the possible influence of humans on flora and fauna and the frequency of maintenance works that might disturb visitors. The necessary information was gained through data collection at the site (e.g. quantity of maintenance works) and by values available in the literature (e.g. erosion rates of geological materials). The application of this method shows that this geosite can support 2050 visitors per day (or 748,250 per year) roughly ten times the number of visitors that was registered during the fieldwork (Lima 2012). It should be emphasized that the carrying capacity was calculated for the whole area of the geosite and not for each one of the geological features (presented in Table 1). For example, the area of the littoral cone is just $X \%$ of the total area of the geosite. This means that the result of the carrying capacity should be used as a general indicator for the whole geosite, and that it gives no direct hints for the management of geosite's features.

\section{Conclusions}

In spite of the designation in 2005 of the "Ponta da Ferraria e Pico das Camarinhas" geosite as a Natural Monument, no management plan has ever been implemented in order to ensure the maintenance of its natural and cultural features. However, due to a relatively high number of visitors (taking into consideration the average number of tourists in the island) and consequent pressure on geological elements, some management actions were implemented (e.g. partial fence at the littoral cone). Before this study, these management actions were never validated or monitored in order to assess their efficiency.

During this work, several features and sub-features were identified in the geosite. The littoral cone is the one with higher vulnerability and for this reason, it was chosen to be monitored during a one-year period in order to evaluate eventual impacts of visitors. Erosion caused by trampling the cone by visitors was assumed to be one of the major threats.

However, the results of monitoring showed that the percentage of visitors who climb the cone is very small (around $4 \%$ of all visitors) probably due to the existence of a sign that prohibits it. The presence of a ropy-type fence on the littoral cone seems to have no significant influence on the tourist behaviour, since the number of visitors walking on the littoral cone is almost the same with or without the fence. Thus, the existence of a fence on the littoral cone seems to be necessary only in limited areas (e.g. near old paths), which also minimize the visual impact on the geosite. During the monitoring period, photographical records show that the paths on the cone are in constant evolution, mainly due to erosion caused by natural and/or anthropogenic factors.

The evaluation of the effect on visitors of the information provided by the interpretative panel located in the viewpoint was not a major aim of this work. However, the research showed that most visitors did not spend enough time to read the panel and that some of them took pictures of it, perhaps to read it in another occasion.

A total of 15,903 visitors were registered during the monitoring period (77 days). A total of 72,789 visitors (tourists and locals) are estimated to visit this geosite annually. A maximum of 850 persons visited the geosite in a single day. This number of visitors is well below the geosite's carrying capacity of 2050 visitors per day determined in this research. However, it should be taken into account that the carrying capacity is calculated in relation to several factors (physical, social, environmental, biological and management) that could change 
over time. The carrying capacity values should be considered provisory and dynamic, and they ought to be reviewed in case of significant changes in any of the above mentioned factors and also when the conservation status of the geosite shows signs of apparent decline. Concerning the obtained values for the carrying capacity, it is highly unlikely that the 2050 visitors per day will ever be reached under the present conditions of the geosite due, for instance, to the limited number of allowed vehicles in the car park or to the size of the natural thermal pool that is an important attractor of visitors. In addition, that the figure would represent the total number of visitors a day in the geosite and not the number of visitors in the same time in the geosite.

The analysis of the evolution of the conservation status of a geosite plays a very important role in the control of its eventual decline. This decrease of relevance could be caused either by direct degradation of geological features or by deficient site maintenance. The results of the monitoring carried out in this particular geosite of the Azores UNESCO Global Geopark are a major asset for site managers. It is expected that the main conclusions of the study will contribute for the improvement of the geoconservation strategy for the Geopark.

Acknowledgments This work is co-funded by the European Union through the European Regional Development Fund based on COMPETE 2020 (Programa Operacional da Competitividade e Internacionalização), project ICT (UID/GEO/04683/2013) with reference POCI-01-0145-FEDER-007690 and national funds provided by Fundação para a Ciência e Tecnologia. We also thank the Azores Geopark management body and staff for the support to the master thesis at the aim of which this monitoring was carried out. Authors express their gratitude for the comments made by Dr. Juana Vegas and by an anonymous reviewer, who contributed to improve the final quality of the manuscript.

\section{References}

Acciaiuoli L (1953) Le Portugal hydromineral, 1st edn. Direction générales des Mines et des Services Géologiques, Lisbonne

Brilha J (2016) Inventory and quantitative assessment of geosites and geodiversity sites: a review. Geoheritage 8(2):119-134

Carvalho M, Mateus A, Nunes J, Carvalho J (2009) Caracterização da água termal da Ferraria (S. Miguel, Açores): origem e evolução composicional. In: Encontro Internacional de Termalismo e Turismo Termal: III Fórum Ibérico de Águas Engarrafadas e Termalismo, Furnas, Açores, pp 103-112

Cifuentes M (1992) Determinacion de Capacidade de Carga Turística en Áreas Protegidas. CATIE, Turrialba

Díez-Herrero A, Vegas J, Carcavilla L, García-Cortés A, Martín A, Gutiérrez-Marco J, Rábano I, Baeza E, Gómez-Heras M (2015)
Geoindicadores para la evaluación de los procesos geológicos que afectan al estado de conservación y uso público del patrimonio geológico. Cuadernos del Museo Geominero, No. 8, IGME, Madrid

García-Cortés Á, Vegas J, Carcavilla L, Díaz-Martínez E (2012) Un sistema de indicadores para la evaluación y seguimiento del estado de conservación del patrimonio geológico. Geo-Temas 13:12721275

Henriques M, Pena dos Reis R, Brilha J, Mota T (2011) Geoconservation as an emerging geoscience. Geoheritage 3(2):117-128

Lima E (2007) Património Geológico dos Açores: valorização de locais com interesse geológico das áreas ambientais, contributo para o ordenamento do território. Dissertação para obtenção do grau de Mestre, Universidade dos Açores

Lima E (2009) Azorean Geological Heritage: valuing geosites in environmental protected areas, contribution to the land planning. In: International Intensive Course on Geoparks 2009 "Earth Heritage and Nature Conservation: Geopark's Management and Action Plans on Sustainable Tourism". Lesvos Island, pp 87-88

Lima E, Nunes J, Costa M, Porteiro A (2010) Main geosites of the Azores Geopark Project. In: M.A. Lamolda et al. (Ed.). Abstract Geoevents, Geological Heritage and the Role of the IGCP. Caravaca de la Cruz, pp 227-229

Lima A (2012) Estratégias de monitorização do geossítio Ponta da Ferraria e Pico das Camarinhas, ilha de S. Miguel: contributo para a gestão sustentada do património geológico do Geoparque Açores. Dissertação para obtenção do grau de Mestre, Universidade do Minho

MacDonald L, Smart A, Wissmar R (1991) Monitoring guidelines to evaluate effects of forestry activities on streams in the Pacific northwest and Alaska. U.S. Environmental Protection Agency, Seattle

Marion J, Leung Y (2011) Indicators and protocols for monitoring impacts of formal and informal trails in protected areas. Journal of Tourism and Leisure Studies 17(2):215-236

Moore R (1991) Geologic map of São Miguel, Azores. Scale 1:50.000. U.S. Geological Survey, Denver

Nunes J, Lima E (2009) The Ponta da Ferraria lava delta geosite: scientific, educational, environmental, historical and economic (geotouristic) value. Proceedings of 8th European Geoparks Conference, C. Neto de Carvalho \& Joana Rodrigues (Ed.). Idanha-a-Nova, pp 161-166

Nunes J, Lima E, Ponte D, Costa M, Castro R (2011) Azores Geopark application. Associação Geoparque Açores, Horta

Portugal M (2002) Monitorização de planos de ordenamento - caso de estudo: Parque Nacional da Peneda-Gerês. Dissertação para obtenção do grau de Mestre, Universidade do Porto

Spellerberg I (1991) Monitoring Ecological Change, 1st edn. Cambridge University Press, Cambridge

Vegas J, Mata P, Sánchez España J, Morellón M, Salazar A, Rodríguez J, Valero-Garcés B, Carcavilla L (2015) Evolución del estado de conservación de lugares de interés geológico sometidos a modificaciones antrópicas. Cuadernos del Museo Geominero, No. 8, IGME, Madrid

Wimbledon W, Barnard A, Peterken A (2004) Geosite management - a widely applicable, practical approach. In: Parkes MA (ed) Natural and cultural landscapes - the geological foundation. Royal Irish Academy, Dublin, pp. 187-192 